\title{
FAKTOR-FAKTOR YANG MEMPENGARUHI PERILAKU KONSUMEN SARUNG TENUN IKAT LAMONGAN
}

\author{
Rachmad Hidayat \\ Jurusan Teknik Industri \\ Universitas Trunojoyo Madura \\ Email: hidayat trunojoyo@yahoo.co.id
}

\begin{abstract}
This his research is done in Lamongan which located in countryside of Parengan, district of Maduran, sub-province of Lamongan. The effort that developed is sarung tenun ikat production. Target of this research is to identify requirement of consumer and know dominant factor which generate tendency of enthusiasm buy of consumer to sarung tenun ikat product. At this research, intake of sampel done by purposive and data collected through kuisioner counted 100 responden. Quisioner compiled in the form of Likert Scale and data analysed by using factor analysis. Result of research indicate that to identify attribute of quality is type of sarung tenun ikat, colour of sarung tenun ikat, accuration of jacquards of sarung tenun ikat, result of jacquards of sarung tenun ikat, materials used not easy to tear, and quality as according to price. most dominant factor is brand and quality. Which the included in quality factor and brand is $2^{\text {nd }}$ attribute (color), $3^{\text {rd }}$ attribute (accuration), $5^{\text {th }}$ attribute (materials) and $8^{\text {th }}$ (brand).
\end{abstract}

Keyword: dominant factor, identify attribute of quality and analysis factor.

\section{PENDAHULUAN}

Semakin deras arus informasi saat ini adalah dampak dari globalisasi, hal ini menyebabkan semakin pesatnya perkembangan ilmu pengetahuan dan teknologi disegala bidang yang mendorong munculnya berbagai jenis usaha, baik yang dilakukan oleh pemerintah atau swasta. Dalam melihat kondisi saat ini banyak pengusaha yang berusaha untuk memanfaatkan peluang yang ada. Salah satu peluang tersebut yaitu usaha produksi sarung. Sarung merupakan salah satu pakaian yang dipakai oleh sebagian besar masyarakat Indonesia. Atribut produk segala jenis busana pada umumnya berhubungan dengan budaya dan adat istiadat komunitas pemakainya. Demikian dengan sarung, atributnya sangat dipengaruhi oleh budaya masyarakat Indonesia.

Bukan hanya di Indonesia saja tetapi dimanca negara sarung juga banyak digunakan. Seperti di negara-negara Asia yaitu Malaysia, Brunei, Kamboja, India dan Pakistan, serta telah diperkenalkan kepada orang-orang di belahan Timur Tengah. Sehigga industri sarung lebih menarikuntuk dikelolah dan diekspor. Sarung juga memiliki daya tarik tersendiri untuk dikembangkan, karena potensi bangsa Indonesia sebagai produsen dan konsumen sehingga dapat ikut mengembangkan perekonomian bangsa. Demikian halnya denga Sarung Tenun Ikat yang terletak di Desa Parengan Kecamata Maduran Kabupaten Lamongan. Usaha yang dikembangkan adalah produksi sarung tenun ikat, dimana produksi sarung tenun ikat ini diproduksi untuk keperluan masyarakat baik sebagai pakaian sehari-hari, acara resmi atau pada kondisi santai. Seiring dengan banyaknya kebutuhan masyarakat akan sarung tenun ikat, maka akhir-akhir ini bayak sekali muncul perusahaan yang memproduksi hasil yang sejenis. Hal ini menyebabkan persaingan diantara perusahaan sarung untuk merebut konsumen.

Kurang minatnya konsumen dalam membeli sarung tenunikatiniadalahsalah satunyadiakibatkan kurangnya kemampuan dalam pemasaran dan penjualan untuk memotifasi serta membentuk persepsi dan sikap positif dari konsumen untuk menyukai sarung tenun ikat. Dalam keadaan seperti ini membutuhan strategi pemasaran yang tepat 
untuk memenuhi dan melayani kebutuhan akan keinginan konsumen. Pada awalnya konsumen mungkin saja menyatakan kebutuhan dan keinginan mereka sedemikian rupa, tetapi pada akhirnya akan bertindak yang sebaliknya. Oleh karena itu untuk menarik minat konsumen sampai akhirnya pada proses pembelian, yang perlu dilakukan oleh perusahaan yaitu tidak hanya dipengaruhi oleh faktor marketing mix saja tetapi pihak perusahaan juga harus memperhatikan atribut-atribut apa saja yang mempengaruhi tingkah laku para konsumennya. Dengan menyadari arti pentingnya pemasaran dan latar belakang diatas maka akan dilakukan penelitian yang ditekankan pada analisa perilaku konsumen terhadap pembelian sarung tenun ikat.

\section{Rumusan Masalah}

Dari latar belakang permasalahan diatas maka permasalan utama yang dibahas adalah sebagai berikut :

1. Mengidentifikasi atribut kualitas dalam memilih produk sarung tenun ikat.

2. Faktor apa saja yang paling dominan yang menimbulkan kecenderungan minat beli konsumen dalam memilih produk sarung tenun ikat Lamongan.

Tujuan Dan Penelitian

Berdasarkan perumusan masalah di atas, maka penelitian ini mempunyai tujuan sebagai berikut:

1. Untuk mengidentifikasi atribut kualitas dalam memilih produk sarung tenun ikat.

2. Untuk mengetahui faktor dominan yang menimbulkan kecenderungan minat beli konsumen dalam memilih produk sarung tenun ikat Lamongan.

Manfaat penelitian ini di harapkan dapat berguna bagi :

1. Memberikan informasi atau masukan terhadap masalah yang dihadapi serta dapat dijadikan bahan pertimbangan guna mengambil langkahlangkah selanjutnya untuk dapat meningkatkan volume penjualan.

2. Dapat digunakan sebagai acuan dalam penelitian lebih lanjut, terutama yang mengambil obyek produk yang sama dalam kerangka pelaksanaan strategi pemasaran yang efektif dan memberikan nilai tambah pada khasanah ilmu pengetahuan.

\section{Perilaku Konsumen}

Perilaku konsumen merupakan manivestasi dari perilaku manusia yang sangat kompleks dan cukup sulit untuk dipelajari, hal ini disebabkan oleh banyaknya atribut yang berpengaruh dan cenderung untuk berinteraksi. Oleh karena itu, untuk memudahkan mempelajarinya, banyak dikembangkan model-model sebagai penyederhanaan dari bentuk nyatanya. Menganalisa perilaku konsumen akan lebih mendalam dan berhasil apabila dapat memahami aspek psikologi manusia secara keseluruhan. Kekuatan sosial budaya dan prinsip-prinsip ekonomis serta strategi pemasaran. Dengan analisa perilaku konsumen, perusahaan akan mempunyai pandangan yang lebih luas dan akan mengetahui kesempatan baru yang berasal dari belum terpenuhinya kebutuhan konsumen.

Perilaku konsumen terbagi menjadi dua bagian, yang pertama adalah perilaku yang tampak, atributatribut yang termasuk kedalamnya adalah jumlah pembelian, waktu, karena siapa, dengan siapa dan bagaimana konsumen melakukan pembelian. Yang kedua adalah perilaku yang tak tampak, atributatributnya antara lain adalah persepsi, ingatan tehadap informasi dan perasan kepemilikan oleh konsumen. Perilaku konsumen menentukan dalam proses pengambilan keputusan membeli yang tahapnya dimulai dari pengenalan masalah yaitu berupa desakan yang membangkitkan tindakan untuk memenuhi dan memuaskan konsumen.

\section{Produk (Product)}

Produk merupakan titik sentral dari kegiatan marketing. Produk adalah kombinasi barang dan jasa yang ditawarkan oleh perusahaan kepada pasar. Jika tidak ada pasar, tidak ada pemindahan hak milik maka tidak ada marketing. Semua kegiatan marketing lainnya dipakai untuk menunjang gerakan produk. Suatu hal yang perlu diingat adalah bagaiman hebatnya usaha promosi, distribusi dan harga jika tidak diikuti dengan produk yang bermutu, disenangi konsumen, maka usaha marketing mix ini tidak akan berhasil. Oleh karena itu, perlu dikaji produk apa yang akan dipasarkan, bagaiman selera konsumen saat ini, apa kebutuhan dan keingina konsumen. Konsumen membeli barang karena mereka membutuhkannya. Namun konsumen tidak membeli barang, hanya sekedar memperoleh barang saja, akan tetapi ada maksud lain dibalik barang itu.

Beberapa atribut dari produk adalah kualitas, nama merek, bentuk, ukuran dan kemasan, karakter dan ragam produk. Manfaat yang ditawarkan 
produsen dikomunikasikan melalui atribut produk. Menurut Zaltman, pandangan konsumen terhadap manfaat suatu produk hanya didasarkan pada apa yang diberikan produk. Oleh karenaitu, bila dikaikan dengan loyalitas konsumen, kami mempromosikan atribut produk mempengaruhi loyalitas konsumen melalui kepercayaan terhadap merek. Kepercayaan merek merupakan persepsi konsumen terhadap kehandalan produk. Atribut produk diproposikan menjadi salah satu bentuk stimuli dalam proses pembentukan persepsi konsumen.

Beberapa atribut produk antara lain:

a. Kualitas produk merupakan kemampuan produk untuk menjalankan fungsinya, termasuk juga mencakup daya tahan, kehandalan, ketepatan, kemudahaan penggunaan, perbaikan serta atribut bernilai lainnya. Konsumen mempunyai persepsi terhadap keseluruhan kualitas atau mutu atas keunggulan suatu produk berkenaan dengan maksud yang diharapkan. Artinya kemampuan dari suatu hasil yang diterima konsumen selama mengkonsumsi produk benarbenar sudah sesuai dengan harapan, persepsi tentang kualitas produk akan positif.

b. Fitur produk mengarah kepada alat-alat yang digunakan untuk membedakan produk perusahaan dengan lainnya. Perusahaan yang mampu memperkenalkan fitur baru sesuai kebutuhan konsumen merupakan cara efektif memenangkan persaingan.

c. Desain produk berbeda dengan gaya (style). Gaya hanya menggambarkan tampilan produk yang tampak secara fisik. Desain produk bukan tentang penampilan saja, tetapi lebih mengarah kepada peningkatan kinerja produk.

d. Kemasanan menjadi bagaian dari sebuah produk, membuatnya menjadi luwes, lebih aman dan lebih mudah diergunaka. Kemasan juga mempermudah konsumen untuk membedakan produk dibandingkan dengan produk pesaing. Menurut Kotler dan Amstrong (2001 : 367) pengemasan adalah kegiatan untuk merancang dan memproduksi wadah dan pembungkus untuk suatu produk.

e. Merek adalah nama, istilah, tanda, simbol, rancangan atau kombinasi dari hal-hal tersebut yang dimaksudkan untuk mengidentifikasi barang atau jasa seseorang atau sekelompok penjual dan untuk membedakan dari produk pesaing. Merek sebenarnya janji penjual secara konsisten memberikan keistimewaan, manfaat dan jasa tertentu kepada pembeli.

\section{Harga (Price)}

Harga adalah jumlah uang yang harus dibayar oleh pelanggan untuk memperoleh barang dan jasa. Masalah kebijakan harga juga turut menentukan keberhasilan permasalahan produk. Kebijakan dapat dilakukan pada setiap tingkatan distribusi, seperti oleh produsen, grosir atau pedagang eceran. Banyak strategi harga yang dapat dilakukan pada setiap tingkatan distribusi tersebut, antara lain strategi interved pricing. Dalam hal ini produsen mencoba menetapkan harga eceran tertinggi (HET). Setelah HET ditetapkan, produsen mencoba mengkalkulasi harga untuk pedagang eceran, harga untuk grosir, dan akhirnya harga untuk pabrik.dengan demikian, produsen menetapakan nilai tambah untuk masing - masing lembaga penyalur dan mengawasi harga jual produknya.

Pada umumnya ada tiga strategi harga yang dapat diikuti oleh produsen, tergantung pada keadaan produknya. Strategi tersebut adalah :

a. Skiming Price adalah menetapkan harga setinggitingginya. Strategi ini hanya mungkin, apabila produknya diarahkan kepada konsumen yang berpenghasilan tinggi, dan ini merupakan produk baru yang samgat istimewa. Untuk memperoleh produk tersebut, telah dikeluarkan biaya eksperimen dan laboratorium yang sangat tinggi. Kemudian, harga barang-barang tersebut berangsur-angsur diturunkan.

b. Penetration Price bertujuan untuk meneroboskan produk kepasar, karena banyak barang sejenis yang sudah ada dipasar. Oleh sebab itu, produsen mencoba merebut pasar dengan harga rendah.

c. Live and let police (Strategi yang mencoba mengikuti harga pasar). Walaupun misalnya produsen dapat menghasilkan barang dengan harga pokok rendah, dan mampu menjualnya dengan harga yang lebih murah, namun produsen tidak mau menurunkan harganya. Akan lebih baik baginya mengikuti harga pasar, karena ada kekhawatiran jika harga diturunkan akan timbul perang harga dan ini sangat berbahaya.

3. Promosi (Promotion)

Promosi berarti aktivitas yang mengkomunikasikan keunggulan produk dan membujuk pelanggan untuk membelinya. Promosi pada zaman pemasaran modern sekarang ini tidak dapat dibaikan. Promosi ini sangat berkembang 
pada masa "selling concept" dimana produsen sangat mengandalkan, memberikan harapan tinggi akan meningkatnya penjualan dengan menggunakan promosi. Pada akhir-akhir ini para produsen mulai memperhatikan para konsumen, tidak saja dengan cara-cara promosi, akan tetapi juga denga memperhatikan selera mereka, dengan cara membuat barang yang memenuhi kebutuhan dan keinginan konsumen. Produsen mulai memperhatikan produk yang sesuai dengan keinginan konsumen. Antara promosi dengan produk tidak dapat dipisahkan, ini adalah dua hal yang saling berpengaruh untuk menuju suksesnya pemasaran. Harusnya ada keseimbangan, produk baik, sesuai dengan selera konsumen yang diikuti dengan teknik promosi yang tepat, akan sangat membantu suksesnya usaha pemasaran. Bauran promosi terdiri dari :

a. Periklanan (Advertising) adalah semua bentuk kimunikasi nonpersonal tentang gagasan, barang, atau jasa yang dibiayai oleh sponsor tertentu. Periklanan dapat berbentuk media cetak, brosur, billboard, atau poster.

b. Hubungan Masyarakat (Public Relation) adalah kegiatan promosi yang ditujukan kepada public untuk mengkomunikasikan citra positif produk atau perusahaannya dan untuk mempromosikan niat baik. Bentuknya dapat dilakukan dengan menjadi sponsor pada peristiwa atau kegiatankegiatan tertentu.

c. Promosi Penjualan (Sales Promotion) adalah beragam insentif jangka pendek untuk mendorong keinginan mencoba atau membeli suatu produk atau jasa. Bentuk-bentuk dari promosi penjualan seperti, pameran, pembagian voucher, pembagian sampel produk, dan lainlain.

\section{Faktor - Faktor yang Mempengaruhi Perilaku Konsumen}

Konsumen merupakan pihak yang memiliki kekuatan penawaran yang tinggi terhadap produk yang ditawarkan sebuah perusahaan. Banyak faktor yang mempengharui tindakan dan perilaku konsumen. Perilaku konsumen dalam melakukan pembelian dipengaruhi beberapa faktor. Menurut Kotler (1997 : 153), faktor-faktor tersebut adalah kebudayaan, sosial, kepribadian dan psikologi.

\begin{tabular}{|c|c|c|c|c|}
\hline & \\
\hline \multicolumn{2}{|l|}{ Kebudayaan } & & & \\
\hline \multirow[t]{2}{*}{ Budaya } & Sosial & & & \\
\hline & $\begin{array}{l}\text { K e lo m p o k } \\
\text { Acuan }\end{array}$ & Pribadi & & \\
\hline \multirow{3}{*}{ Sub-Budaya } & & Usia & Psikologis & \\
\hline & & Pekerjaan & Motivasi & \\
\hline & $\begin{array}{l}\text { Keluarga } \\
\text { Peran dan } \\
\text { Status }\end{array}$ & $\begin{array}{l}\text { Keadaan Ekonomı } \\
\text { Gaya Hidup } \\
\text { Kepribadian }\end{array}$ & $\begin{array}{l}\text { Persepsi } \\
\text { Pengetahuan } \\
\text { Keyakinan } \\
\text { dan sikap }\end{array}$ & Pembeli \\
\hline
\end{tabular}

\section{Gambar 1 : Faktor - Faktor Yang Mempengaruhi Perilaku Konsumen}

a. Faktor kebudayaan

Lingkungan sosial budaya ini akan membentuk perilaku konsumen, termasuk di dalamnya budaya daerah, personal value, demografi, dan kepedulian konsumen yang semakin meningkat terhadap manfaat sosial. Dunia ini sangat kaya akan budaya sehingga dapat mempengaruhi gaya hidup masyarakat dan akhirnya sangat mempengharui perilaku konsumen secara signifikan. Khusus bagi daerah berkembang yang memiliki pengalaman dalam mereformasi ekonomi memiliki kesempatan yang lebih besar baik dalam mengubah masyarakatnya terutama gaya hidup maupun dalam hal pengambilan keputusan pembelian. Faktor kebudayaan mempunyai pengaruh yang luas dan mendalam terhadap perilaku yang mencakup budaya (kultur), sub budaya dan kelas sosial. Budaya adalah fakta dan simbol yang komplek, diciptakan manusia dari generasi ke generasi sebagai penentu dan pengatur perilaku manusia dalam bermasyarakat. Faktor budaya adalah determinan yang paling mendasar dari keinginan dan perilaku individu. Perilaku konsumen sangat ditentukan oleh budaya yang tercermin dalam acara hidup, kebiasaan dan tradisi dalam permintaan produk. Setiap 
perilaku atau tindakan konsumen ditata dan dikendalikan oleh berbagai sistem dan norma budaya. Untuk itu perusahaan dituntut untuk mengerti akan implikasi dari kebudayaan dimana perusahaan itu berada. Sub budaya adalah kebudayaan yang ada pada suatu golongan masyarakat yang berbeda dengan masyarakat yang lain. Sub budaya memberika lebih banyak ciri-ciri dan sosialisasi khusus bagi para anggotanya. Sub budaya mencakup kebangsaan, agama, kelompok ras dan daerah geografis. Kelas sosial adalah pembagian yang relatif homogen dan permanent yang tersusun secara hirarki dan memiliki anggota dengan nilai, minat dan perilaku yang serupa. Stratifikasi kelas sosial adalah dari penghasilan, pekerjaan, kekayaan dan pendidikan. Setiap kelas sosial menunjukkan prefensi produk dan merek yang berbeda-beda, sehingga dapat digunakan untuk mensegmentasikan pasar dan meramalkan tanggapan konsumen terhadap kegiatan pemasaran konsumen.

b. Faktor sosial

Selain faktor budaya, perilaku juga dipengaruhi oleh faktor-faktor sosial seperti kelompok acuan, keluarga serta peran dan status. Kelompok acuan adalah kelompok yang mempunyai pengaruh langsung atau tidak langsung terhadap sikap dan perilaku seseorang. Kelompok acuan dapat mempengaruhi seseorang terutama dalam 3 (tiga) hal, yaitu :

(1) Menghadapkan seseorang pada perilaku dan gaya hidup baru.

(2) Mempengaruhi perilaku dan konsep diri seseorang.

(3) Menciptakan tekanan untuk mematuhi apa yang mungkin mempengaruhi pilihan produk dan merek aktual seseorang.

Peran dan status seseorang yang berantisipasi di berbagai kelompok akan membawa pada posisi tertentu. Peran meliputi kegiatan yang diharapkan akan dilakukan seseorang dan didalam peran terdapat status. Setiap orang akan menjalankan peran tertentu yang akan mempengaruhi perilakunya, sehingga dimungkinkan adanya perilaku yang berbeda dalam setiap peran.

c. Faktor pribadi

Temasuk faktor pribadi adalah usia, pekerjaan, keadaan ekonomi, gaya hidup, dan kepribadian. Usia berhubungan erat dengat perilaku dan selera seseorang. Bertambanya usia biasanya diikuti juga dengan berubahnya selera terhadap produk. Faktor pekerjaan juga mempengaruhi pola konsumsi seseorang, sedangkan keadaan ekonomi cenderung mempengaruhi pemilihan barang dan jasa. Gaya hidup adalah pola hidup seseorang yang diekspresikan dalam aktifitas, minat dan opini yang menggambarkan keseluruhan diri seseorang dalam berinteraksi dengan lingkungan, sedangkan kepribadian adalah karakteristik psikologi yang berbeda dari seseorang yang menyebabkan tanggapan yang relatif konsisten dan bertahan lama terhadap lingkungan. Dengan kepribadian seseorang akan mempunyai konsep diri atau citra pribadi yang khas.

d. Faktor psikologi

Ada empat faktor psikologi yang utama yang mempengaruhi pemilihan pembelian yaitu motivasi,persepsi,pengetahuansertakenyakinan dan sikap. Motivasi adalah kebutuhan yang mendorong seseorang untuk bertindak, sedangkan persepsi adalah proses bagaimana seseorang individu memilih, mengorganisasi dan menginterprestasikan masukan-masukan informasi untuk menciptakan gambaran yang berarti.Pengetahuanataupembelajaran diartikan sebagai perubahan dalam perilaku seseorang yang timbul dari pengalaman. Sebagian besar perilaku merupakan hasil dari belajar melalui kombinasi tanggapan balajar dan pengakuan. Teori pembelajaran dapat digunakan sebagai dasar untuk membuat dan memasarkan barang dan jasa.

Keyakinan adalah pemikiran deskriptif yang dianut seseorang tentang suatu hal, sedangkan sikap diartikan sebagai evaluasi, perasaan, emosional dan kecenderungan tindakan yang menguntungkan atau tidak menguntungkan dan bertahan lama dari seseorang terhadap beberapa obyek atau gagasan. Sikap akan mengarahkan seseorang berperilaku secara konsisten terhadap suatu objek tanpa harus mengekspresikan atau bereaksi dengan cara yang sama atau caracara baru. Sikap seseorang membentuk suatu pola yang konsisten dan untuk mengubah suatu sikap mungkin diperlukan penyesuaian yang besar dengan sikap-sikap yang lain. Untuk perusahaan sebaiknya menyesuaikan produknya dengan sikap yang telah ada. Secara umum manfaat mempelajari perilaku konsumen 
adalah membantu manajemen mencapai sasaran yang diinginkan secara efektif. Dalam memahami respon konsumen baik berdasarkan riset formal maupun tidak, yang menjadi unsur utama kesuksesan adalah pengetahuan tentang konsumen tersebut. Untuk dapat memahami perilaku konsumen bukanlah pekerjaan mudah. Tidaklah cukup dengan mengandalkan pengalaman penjualan sehari-hari karena akan sulit untuk menganalisa keinginan, persepsi dan preferensi konsumen, sebab keinginan, persepsi dan preferensi konsumen dapat berubah sewaktu-waktu.

\section{METODE}

\section{Pemilihan Obyek / Survey Awal}

Obyek penelitian yang dipilih dalam penelitian ini adalah daerah lamongan. Dalam survey awal ini, merupakan tahapan yang dilakukan dengan tujuan untuk mengetahui dan mempelajari bagaimana kondisi dan keadaan obyek yang akan diteliti dan untuk menentukan langkah-langkah selanjutnya dalam penelitian.

\section{Identifikasi Atribut Penelitian}

Atribut yang digunakan dalam penelitian ini adalah sebagai berikut:

1. Jenis beragam

2. Warna beragam

3. Kerapian tenunan

4. Kehalusan tenunan

5. Bahan kuat atau tidak mudah koyak

6. Kemasan menarik

7. Tulisan pada kemasanan menarik

8. Merek mudah diingat

9. Harga kompetitif

10. Adanya diskon

11. Harga sesuai dengan kualitas

12. Promosi menarik

13. Lokasi penjualan strategis

14. Persediaan barang atau produk

\section{Pengumpulan Data}

Pada penelitian ini kuisioner digunakan sebagai alat pengumpulan data. Kuisioner disusun berdasarkan atribut-atribut yang telah ditentukan sebelumnya. Pengisian kuisioner awal ini diberikan kepada konsumen untuk mengetahui apakah pertanyaan-pertanyaan yang dibuat mudah dan dipahami dan dimengerti oleh responden. Sehingga apabila pertanyaan yang terdapat dalam kuisioner awal ini sulit dimengerti dan dipahami maka perlu diadakan perbaikkan. Pengisisan kuisioner awal 6 dilakukan diwilayah sekitar Lamongan minimal 30 responden.

Data yang diambil merupakan data primer yaitu data yang diperoleh langsung dari jawaban responden. Prosedur pengambilan danpengumpulan data dilakukan dengan teknik sebagai berikut :

1. Kuesioner, yaitu pengisian pertanyaan yang ditujukan kepada konsumen untuk dijawab berdasarkan pendapatnya. atribut yang digunakan dalam kuisioner menggunakan skala penilaian model Likert, dengan rentang penilaian dari 1 untuk sikap yang sangat setuju sampaidengan 5 untuksikap sangat tidak setuju. Pengisian kuisioner ini dengan menggunakan metode poprosive, yaitu pengambilan sampel sesuai dengan kebutuhan.

2. Wawancara, yaitu melakukan tanya jawab secara langsung dengan responden. Tujuan wawancara adalah untuk mendukung teknik kuisioner, terutama bila ada yang kurang jelas.

\section{Uji Validitas dan Reabilitas}

1. Uji validitas

Uji validitas adalah suatu ukuran yang menunjukkan tingkat-tingkat keabsahan (validitas) suatu alat ukur (Arikunto, 1998 : 160). Sebuah alat ukur dikatakan valid apabila mampu mengukur apa yang diinginkan dan menghasilkan data dari atribut yang akan diteliti secara tepat.

Untuk mencari validitas dapat menggunakan rumus korelasi product moment.

$$
r=\frac{\sum x-(x)\left(\sum y\right)}{\sqrt{\left\{\sum x^{2}-\frac{\left(\sum x\right)^{2}}{n}\right\}\left\{\sum y^{2}-\frac{\left(\sum y\right)^{2}}{n}\right\}}} t
$$

dimana :

$\mathrm{r}=$ Indeks korelasi antara 2 atribut yang dikorelasikan

$\mathrm{X}=$ Skor butir atribut bebas

$\mathrm{Y} \quad=$ Skor butir atribut terikat

$\mathrm{N} \quad=$ Jumlah respon

Perhitungan ini menggunakan program SPSS (correlation pearson). Nilai koefisien korelasi yang diperoleh kemudian dibandingkan dengan nilai kritis dari tabel korelasi r. 
Cara menguji : korelasika masing-masing skor item pertanyaan dengan skor tabelnya. Gunakan tingkat signifikansi validitas $\leq 5 \%$, tingkat signifikansi ini menunjukkan derajat konsistensi jawaban semua responden yang menjadi obyek penelitian.

2. Reabilitas

Reabilitas adalah indeks yang menunjukkan sejauh mana alat pengukur dapat dipercaya atau dapat diandalkan. Untuk mencari realibilitas digunakan rumus sebagai berikut:

$$
r_{i}=\left|\frac{k}{(k-1)}\right|\left|1-\frac{\sum \mathrm{s}_{b}^{2}}{\mathrm{~s}_{t}^{2}}\right|
$$

dimana:

$$
\begin{array}{ll}
\mathrm{r} & =\text { Reabilitas instrument } \\
\mathrm{k} & =\text { banyaknya butir pertanyaan atau soal } \\
\sum \sigma_{b}^{2} & =\text { Jumlah varians butir } \\
\sigma_{t}^{2} & =\text { jumlah varians total }
\end{array}
$$

Dengan keputusan hipotesa, yaitu jika koefisien realibiltas interval seluruh item $\left({ }^{r_{i}}\right) \geq{ }^{r_{\text {tabel }}}$ maka keputusannya adalah item instrument dinyatakan reliabel. Dan sebaliknya apabila $\left({ }^{r_{i}}\right) \leq{ }^{r_{\text {tabel }}}$, maka item instrument penelitian tidak reliabel.

\section{Analisis Faktor (Factor Analysis)}

Analisis Faktor (Factor Analysis) merupakan suatu teknik statistik multivariate yang digunakan untuk mengurangi (reduction) dan meringkas (summarization) semua atribut terikat dan saling berketergantungan. Hubungan ketergantungan antara satu atribut dengan yang lain yang akan diuji untuk diidentifikasikan dimensi atau faktornya.

Analisa faktor dipergunakan didalam situasi sebagai berikut :

1. Mengenali dan mengidentifikasi dimensi yang mendasari (underlying dimension) atau faktor, yang menjelaskan korelasi antara suatu set variable.

2. Mengenali atau mengidentifikasi suatu set atribut baru yang tidak berkorelasi (independent) yang lebih sedikit jumlahnya untuk menggantikan suatu set atribut asli yang saling berkorelasi didalam analisa multivariate selanjutnya.

3. Mengenali atau menidentifikasi suatu set atribut yang penting dari suatu set atribut yang lebih banyak jumlahnya untuk dipergunakan didalam analisa multivariate selanjutnya.

Analisis faktor, banyak aplikasinya didalam riset pemasarn, manajemen dan ilmu sosial / kedokteran, untuk pengkelompokannya adalah sebagai berikut:

1. Analisis faktor bisa dipergunakan didalam segmentasi pasar untuk mengidentifikasi atribut yang mendasari yang dipergunakan untuk pengelompokan pelanggan.

2 Didalam riset produk analisis faktor dapat dipergunakan untuk menentukan atribut atau karakteristik merek yang mempengaruhi pilhan pelanggan/pembeli.

3 Didalam studi advertensi, analisa faktor dapat dipergunakan untuk memahami kebiasaan mengkonsumsimedia atau the media consumption habits dari pasar (the target market).

4 Didalam penelitian harga, bias dipergunakan untuk mengenali/mengidentifikasi karakteristik atau sifat - sifat pelanggan/pembeli yang sensitif terhadap harga.

Model analisis faktor dinyatakan dengan formula sebagai berikut :

$$
\mathrm{X}=\mathrm{Aij}+\mathrm{Ai2F}+\mathrm{Ai} 3 \mathrm{~F} 3 \text {. }
$$
$+\mathrm{AimFm}+\mathrm{ViUi}$

dimana :

$\mathrm{Xi} \quad=$ Variable standar yang ke-i

Aij = Koefisien multiple regresi standar dari atribut ke-i pada common factor $\mathrm{j}$

$\mathrm{F}=$ Common Factor

$\mathrm{Vi}=$ Koefisien regresi berganda standar dari

atribut-i pada faktor unik-i

$\mathrm{Ui} \quad=$ Faktor unik atribut-i

$\mathrm{m}=$ Banyaknya common factor

Faktor unik berkorelasi satu dengan yang lain dan dengan common factor. Common factor dapat dinyatakan sebagai kombinasi linier dari atribut yang diteliti., dengan persamaaan :

$$
F=W i 1 X 1+W i 2 X 2+W i 3 X 3+\ldots \ldots \ldots \ldots \ldots+\text { WikXk }
$$

dimana :

$\mathrm{Fi}=$ Faktor ke-i yang diestimasi

$\mathrm{Wi}=$ Bobot atau koefisien score faktor

$\mathrm{Xk}=$ Banyaknya atribut $\mathrm{X}$ pada faktor ke $\mathrm{k}$

\section{HASIL DAN PEMBAHASAN}

Pada pengumpulan dan pengolahan data ini akan menjelaskan tentang identifikasi kebutuhan konsumen serta factor-faktor dominan yang mempengaruhikecenderungan minatbeli konsumen terhadap sarung tenun ikat dengan menggunakan 
analisis faktor. Data yang telah dikumpulkan adalah data yang diperoleh dari kuisioner, yaitu dengan cara pengisian kuisioner kepada responden disekitar wilayah Lamongan. Kuisioner ini meliputi tentang sarung tenun ikat. Langkah-langkah pada pengolahan data ini dilakukan sesuai dengan metode penelitian. Data diolah dengan menggunakan bantuan software SPSS 13.

\section{Uji Validitas}

Telah dilakukan uji validitas data yaitu pada kuisioner awal sebanyak 30 responden yang sah dan didapatkan bahwa data tersebut valid dengan tingkat signifikan $5 \%$ dan nilai $\mathrm{r}_{\text {tabel }}=$ 0,361 . Uji validitas ini digunakan mengetahui seberapa tepat suatu alat ukur mampu melakukan fungsi.

\section{Uji Relibilitas}

Dari pengisian kuisioner awal telah diketahui yaitu adanya jawaban-jawaban para konsumen yang telah disebarkan sebanyak 30 responden, dan telah didapatkan hasil dari pengujian ini dengan menggunakan bantuan program SPSS 13, yaitu nilai alpha cronbach yaitu 0.779 . Dari hasil tersebut diketahui bahwa nilai alpha lebih besar dari nilai tingkat signifikannya sehingga data tersebut dapat dikatakan sebagai data reliabel.

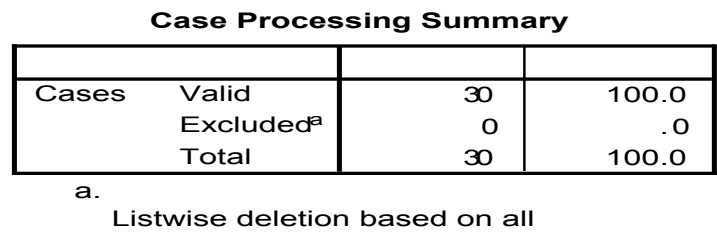

Reliability Statistics

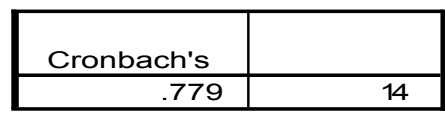

\begin{tabular}{|l|c|c|c|c|}
\multicolumn{7}{|c|}{ Item-Total Statistics } \\
& & $\begin{array}{c}\text { Scale } \\
\text { Variance if }\end{array}$ & $\begin{array}{c}\text { Corrected } \\
\text { Item-Total }\end{array}$ & $\begin{array}{c}\text { Cronbach's } \\
\text { Alpha if Item }\end{array}$ \\
\hline Pertanyaan_1 & Scale Mean if & 27.016 & .581 & .745 \\
Pertanyaan_2 & 27.7000 & 35.321 &. .350 & .815 \\
Pertanyaan_3 & 27.7667 & 28.806 & .451 & .761 \\
Pertanyaan_4 & 27.8333 & 28.075 & .498 & .756 \\
pertanyaan_5 & 27.5667 & 27.909 & .461 & .759 \\
Pertanyaan_6 & 28.1000 & 28.714 & .392 & .766 \\
Pertanyaan_7 & 27.7667 & 28.875 & .480 & .759 \\
Pertanyaan_8 & 28.0000 & 29.586 & .260 & .780 \\
Pertanyaan_9 & 27.8333 & 30.144 & .479 & .764 \\
Pertanyaan_10 & 27.4000 & 29.559 & .413 & .765 \\
Pertanyaan_11 & 27.9667 & 27.757 & .528 & .753 \\
Pertanyaan_12 & 28.0000 & 28.069 & .421 & .764 \\
Pertanyaan_13 & 27.9667 & 28.309 & .494 & .757 \\
Pertanyaan_14 & 27.8000 & 29.821 & .448 & .764 \\
\hline
\end{tabular}

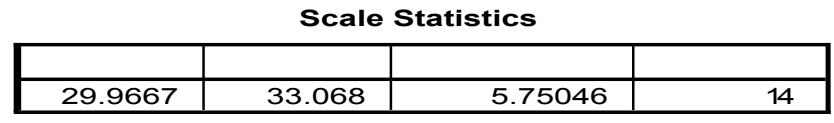

\section{Penentuan Sampel}

Penentuan sampel ini berdasarkan pada pengambilan sampel sesuai dengan kebutuhan peneliti. Untuk mengetahui banyaknya kuisioner resmi yang harus diisi, maka dibawah ini terdapat rumus yang dapat menentukan seberapa banyak kuisioner yang harus diisi.

$$
n \geq \frac{\left(Z_{\mathrm{a} / 2}\right)^{2} P \cdot q}{e^{2}}
$$

Dari kuisioner awal yang disebarkan sebanyak 32 responden, ternyata ada 30 responden yang dianggap benar dan 2 responden dianggap tidak 8 sah.

Dimana :

1. Interval kepercayaan sebesar $95 \%$, didapatkan $\mathrm{Z}_{0,025}=1,96$

2. Tingkat ketelitian $=5 \%$

3. Proporsi sampel yang $\operatorname{sah}(\mathrm{p})=\frac{\boldsymbol{B}}{\mathbf{Z}}=0,94$

4. Proporsi sampel yang cacat

(q) $=\frac{2}{\mathbf{z}}=0,06$

Sehingga : 
$n \geq \frac{\left(Z_{0,025}\right)^{2} P \cdot q}{e^{2}} n \geq \frac{(1, \emptyset)^{2}(0,94) \cdot(0,06)}{(0, \varnothing)^{2}}$

$n \geq 86,7$

$$
n \geq 87
$$

Dari perhitungan diatas maka dapat diketahui jumlah responden yang berada diwilayah sekitar Lamongan yang mendapat kesempatan untuk mengisi kuisioner adalah minimal 87 responden, jadi kuisioner resmi yang akan disebarkan sebanyak 100 responden. Dari 100 responden yang disurvei pada penelitian ini, diperoleh 70 responden yang pernah membeli dan memakai sarung tenun ikat dan 30 responden yang hanya sekedar mengetahui tentang sarung tenun ikat.

\section{Identifikasi Karakteristik Responden}

1. Deskripsi Karakteristik Responden Berdasarkan Jenis Kelamin

\section{Statistics}
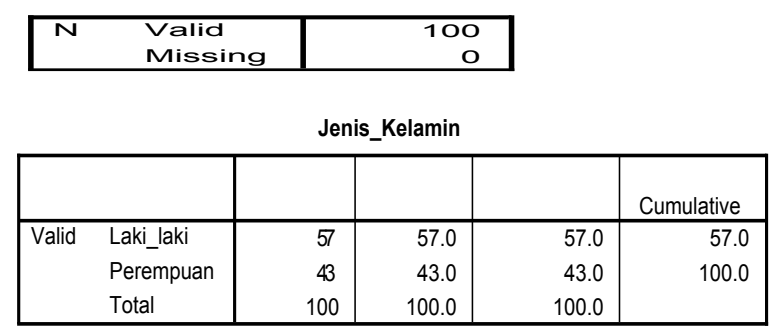

2. Deskripsi Karakteristik Responden Berdasarkan Usia

\section{Statistics}

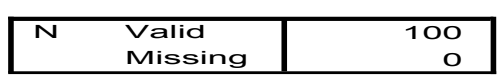

\begin{tabular}{|c|c|c|c|c|c|}
\hline \multicolumn{6}{|c|}{ Usia } \\
\hline & & & & & Cumulative \\
\hline \multirow[t]{4}{*}{ Valid } & 20-30 Tahun & 15 & 15.0 & 15.0 & 15.0 \\
\hline & 31-40 Tahun & 57 & 57.0 & 57.0 & 72.0 \\
\hline & > 41 Tahun & 28 & 28.0 & 28.0 & 100.0 \\
\hline & Total & 100 & 100.0 & 100.0 & \\
\hline
\end{tabular}

3. Deskripsi Karakteristik Responden Berdasarkan Pekerjaan

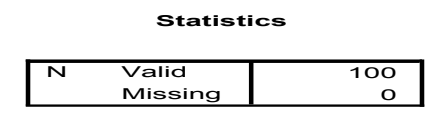

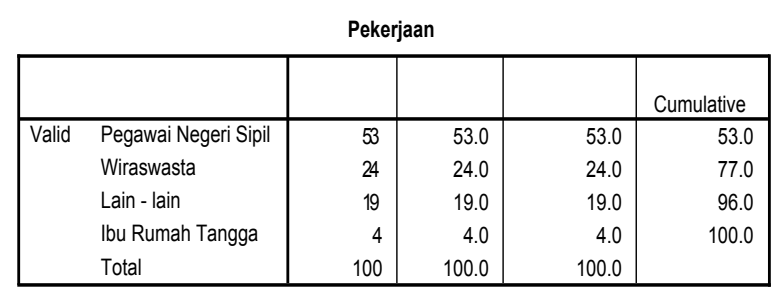

4. Deskripsi Karakteristik Responden Berdasarkan Tingkat Pendidikan

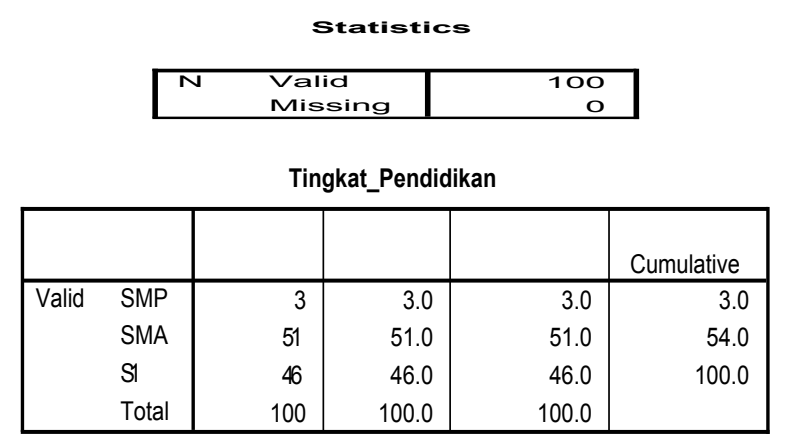

\section{Deskripsi Karakteristik Responden} Berdasarkan Penghasilan

\section{Statistics}
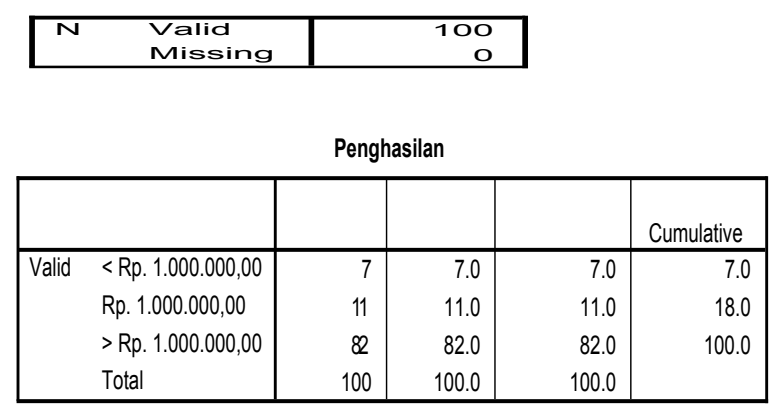

\section{Identifikasi Atribut Kualitas}

Dalam memenuhi kebutuhan konsumen perusahaan harus bisa memahami akan keinginan konsumen. Hal ini akan berpengaruh terhadap jumlah pembelian terhadap barang tersebut. Jika barang tesebut sesuai dengan keinginan konsumen maka jumlah pembelian akan meningkat, dan sebaliknya apabila barang tersebut tidak sesuai dengan konsumen maka konsumen akan beralih pada barang lain. Pada saat ini banyak perusahaan pesaing yang sejenis yang bermunculan. Keadaan ini membuat perusahaan berusaha memenuhi kebutuhan dan mengikuti selera konsumen yang selalu berubah setiap waktu. Sehingga pada penelitian ini dijelaskan identifikasi kebutuhan dari konsumen sarung tenun ikat Lamongan. Hasil dari pengisian kuisioner sebanyak 100 responden terdapat 6 pertanyaan yang meliputi identifikasi 
kebutuhan pelanggan terhadap sarung tenun ikat adalah sebagai berikut:

\section{Jenis Sarung Tenun Ikat}

Dari pengisian kuisioner sebanyak 100 responden pada atribut jenis sarung tenun ikat terdapat 15 responden atau $15 \%$ yang menjawab sangat setuju dan 84 responden atau $84 \%$ yang menjawab setuju bahwa jenis sarung tenun ikat beragam. Sisanya yaitu 1 responden atau $1 \%$ menjawab netral.

\section{Warna Sarung Tenun Ikat}

Dari pengisian kuisioner sebanyak 100 responden pada atribut warna sarung tenun ikat terdapat 29 responden atau $29 \%$ menjawab sangat setuju dan 50 responden atau $50 \%$ menjawab setuju bahwa Warna sarung tenu ikat beragam. Dan sisanya 21 responden atau $21 \%$ menjawab netral.

3. Kerapian Sarung Tenun Ikat

Pada atribut kerapian tenunan sarung tenun ikat terdapat berbagai macam jawaban dari 100 responden. Terdapat 25 responden atau $25 \%$ yang menjawab sangat setuju dan 22 responden atu $22 \%$ yang menjawab setuju bahwa kerapian dari tenunan dibuat sesuai dengan keinginan konsumen. Dan sisanya terdapat 39 responden atau $39 \%$ yang menjawab netral dan 14 responden atau $14 \%$ yang menjawab tidak setuju.

\begin{tabular}{|c|c|c|c|c|c|}
\hline \multicolumn{6}{|c|}{ Kerapian_tenunan_Sarung_tenun_Ikat } \\
\hline & & & & & Cumulative \\
\hline \multirow[t]{5}{*}{ Valid } & Sangat Setuju & 25 & 25.0 & 25.0 & 25.0 \\
\hline & Setuju & 22 & 22.0 & 22.0 & 47.0 \\
\hline & Netral & 39 & 39.0 & 39.0 & 86.0 \\
\hline & Tidak Setuju & 14 & 14.0 & 14.0 & 100.0 \\
\hline & Total & 100 & 100.0 & 100.0 & \\
\hline
\end{tabular}

4. Hasil tenunan sarung Tenun Ikat

Dari 100 responden pada atribut hasil tenunan sarung tenun ikat terdapat berbagai macam jawaban. 19 responden atau $19 \%$ menjawab sangat setuju dan 51 responden atau $51 \%$ menjawab setuju bahwa hasil tenunan dari sarung tenun ikat halus. Sisanya 29 responden atau $29 \%$ menjawab netral dan 1 responden atau $1 \%$ menjawab tidak setuju.
Hasil_Tenunan_sarung_tenun_ikat

\begin{tabular}{|ll|r|r|r|r|}
\hline & & & & Cumulative \\
\hline Valid & Sangat Setuju & 19 & 19.0 & 19.0 & 19.0 \\
& Setuju & 51 & 51.0 & 51.0 & 70.0 \\
& Netral & 29 & 29.0 & 29.0 & 99.0 \\
& Tidak Setuju & 1 & 1.0 & 1.0 & 100.0 \\
& Total & 100 & 100.0 & 100.0 & \\
\hline
\end{tabular}

5. Bahan Tidak Mudah Koyak

Dari 100 responden pada atribut bahan tidak mudah koyak terdaptat berbagai macam jawaban. 22 responden atau $22 \%$ menjawab sangat setuju dan 39 responden atau $39 \%$ menjawab setuju bahwa bahan yang digunnkan dalam pembuatan sarung tenun ikat tidak mudah koyak. Sisanya menjawab netral sebanyak 38 responden atau $38 \%$ dan 1 responden atau $1 \%$ menjawab tidak setuju.

\begin{tabular}{|c|c|c|c|c|c|}
\hline \multicolumn{6}{|c|}{ Bahan_Tidak_mudah_koyak } \\
\hline & & & & & Cumulative \\
\hline & Sangat Setuju & 22 & 22.0 & 22.0 & 22.0 \\
\hline & Setuju & 39 & 39.0 & 39.0 & 61.0 \\
\hline & Netral & 38 & 38.0 & 38.0 & 99.0 \\
\hline & Tidak Setuju & 1 & 1.0 & 1.0 & 100.0 \\
\hline & Total & 100 & 100.0 & 100.0 & \\
\hline
\end{tabular}

6. Kualitas Sesuai Dengan Harga

Dari 100 responden pada atribut kualitas sesuai dengan harga terdapat 54 responden atau 54 $\%$ menjawab sangat setuju dan 37 responden atau $37 \%$ menjawab setuju bahwa harga yang ditawarkan sesuai dengan kualitas dari sarung tenun ikat. Dan sisanya 9 responden atau $9 \%$ menjawab netral.

\begin{tabular}{|c|c|c|c|c|c|}
\hline \multicolumn{6}{|c|}{ Kualitas_sesuai_dengan_harga } \\
\hline & & & & & Cumulative \\
\hline \multirow[t]{4}{*}{ Valid } & Sangat Setuju & 54 & 54.0 & 54.0 & 54.0 \\
\hline & Setuju & 37 & 37.0 & 37.0 & 91.0 \\
\hline & Netral & 9 & 9.0 & 9.0 & 100.0 \\
\hline & Total & 100 & 100.0 & 100.0 & \\
\hline
\end{tabular}

\section{Analisis Faktor}

Analisis faktor merupakan analisis statistik yang bertujuan untuk mengidentifikasi, mengelompokkan dan meringkas factor-faktor yang merupakan dimensi suatu atribut. Dengan analisis faktor, kita dapat menemukan factorfaktor (disebut juga dimensi ataupun komponen) yang dapat mewakili atribut-atribut asli. Pengujian dengan analisis faktor ini menggunakan data yang berasal dari data primer yaitu melalui suatu 
kuisioner dengan menggunakan skala likert. Kuisioner yang dibuat berdasarkan factor-faktor yang mempengaruhi perilaku konsumen dalam pembelian sarung tenun ikat dan terdapat 14 atribut didalamnya, yaitu :

1. Jenis sarung tenun ikat.

2. Warna sarung tenun ikat.

3. Kerapian tenunan sarung tenun ikat.

4. Hasil tenunan sarung ikat.

5. Jenis bahan sarung tenun ikat.

6. Bentuk kemasan sarung tenun ikat.

7. Tulisan pada kemasan sarung tenun ikat.

8. Merek sarung tenun ikat.

9. Harga kompetitif.

10. Diskon pada beberapa produk sarung tenun ikat.

11. Harga sarung tenun ikat sesuai dengan kualitas.

12. Promosi yang dilakukan oleh sarung tenun ikat.

13. Lokasi penjualan sarung tenun ikat.

14. Persediaan barang dari sarung tenun ikat.

Prosedur melakukan analisis faktor adalah sebagai berikut :

1. Mengidentifikasi sasaran / tujuan analisis faktor dan pengukuran atribut-atribut atas dasar skala Likert. Hasil rekapan dari pengisian kuisioner sebanyak 100 responden.

2. Pengujian KMO and Bartlett's test

Pada pengujian KMO and Bartlett's test ini digunakan untuk menguji layak tidaknya analisis faktor dilakukan. Apabila nilai indeks tinggi (berkisar antara 0,5 sampai 1,0), analisis faktor layak dilakukan. Sebaliknya kalau nilai KMO dibawah 0,5 analisis faktor tidak layak dilakukan.

\begin{tabular}{|c|c|c|}
\hline \multicolumn{3}{|c|}{ KMO and Bartlett's Test } \\
\hline $\begin{array}{l}\text { Kaiser-Meyer-OIK } \\
\text { Adequacy. }\end{array}$ & asure of Sampling & .764 \\
\hline $\begin{array}{l}\text { Bartlett's Test of } \\
\text { Sphericity }\end{array}$ & $\begin{array}{l}\text { Approx. Chi-Square } \\
\text { df } \\
\text { Sig. }\end{array}$ & $\begin{array}{r}449.491 \\
91 \\
.000\end{array}$ \\
\hline
\end{tabular}

Dari hasil output program SPSS untuk data 14 pertanyaan yang dijawab oleh 100 responden dalam kuisioner, ternyata didapatkan hasil yang terlihat pada tabel bagian KMO and Barlett's Test yaitu, nilai $K M O$ secara keseluruhan adalah 0,764 . Jadi, analisis faktor ini layak dilakukan karena nilai $K M O$ diatas 0.5 .

Bartlett's test merupakan tes statistik untuk menguji apakah betul atribut-atribut yang dilibatkan berkorelasi. Pada Bartlett's test nilai Chi-Square adalah 444.491, untuk derajat kebebasan (degree of freedom, disingkat df) sebesar 91, memiliki signifikansi 0,000. Jadi, dapat disimpulkan bahwa antar atribut terdapat korelasi.

3. Pengujian Communalitie

Communalities pada dasarnya adalah jumlah varians (bisa dalam prosentase) dari suatu atribut mula-mula yang bisa dijelaskan oleh faktor yang ada.

Hasil dari pengujian Communalities menunjukkan bahwa X1 (jenis sarung tenun ikat), dengan angka 0,905 berarti 90,5\% varians dari atribut jenis sarung tenun ikat bisa dijelaskan oleh faktor yang terbentuk. X2 (warna sarung tenun ikat) dengan angka 0,779 berarti $77,9 \%$ varians dari atribut jenis sarung tenun ikat bisa dijelaskan oleh faktor yang terbentuk. X3 (kerapian tenunan) dengan angka 0,706 berarti $0,706 \% \%$ varians dari atribut jenis sarung tenun ikat bisa dijelaskan oleh faktor yang terbentuk . demikian dengan atribut - atribut lainnya.

\section{Communalities}

\begin{tabular}{|l|l|l|}
\hline & & \\
\hline$X 1$ & 1.000 & .905 \\
$X 2$ & 1.000 & .779 \\
$X 3$ & 1.000 & .706 \\
$X 4$ & 1.000 & .729 \\
$X 5$ & 1.000 & .735 \\
$X 6$ & 1.000 & .673 \\
$X$ & 1.000 & .695 \\
$X 8$ & 1.000 & .731 \\
$X 9$ & 1.000 & .621 \\
$X 10$ & 1.000 & .713 \\
$X 11$ & 1.000 & .691 \\
$X 12$ & 1.000 & .633 \\
$X 13$ & 1.000 & .532 \\
$X 14$ & 1.000 & .670 \\
\hline
\end{tabular}

Semua atribut dapat dijelaskan oleh faktor yang terbentuk dengan ketentuan semakin besar communalities maka semakin erat hubungan atribut yang bersangkutan dengan faktor yang terbentuk.

4. Menentukan Banyaknya Faktor

Pada kuisioner yang telah dibuat terdapat 14 atribut yang dianalis, ternyata dapat 
dikelompokkan menjadi 5 faktor, hal ini ditunjukkan oleh nilai eigenvalues .Dimana nilai eigenvalues yang menunjukkan angka lebih besar dari satu akan membentuk sebuah faktor. Hasil pengolahan dari menentukan banyaknya faktor.

Component Matrix

\begin{tabular}{|l|r|r|r|r|r|}
\hline & & & & \\
\cline { 2 - 6 } & & & & & \\
\hline$\times 1$ & .032 & .014 & -.300 & .358 & .828 \\
$\times 3$ & .858 & -.125 & -.107 & -.004 & -.126 \\
$\times 4$ & -.675 & .063 & .318 & .381 & .011 \\
$\times 5$ & .560 & .335 & .498 & -.003 & .234 \\
$\times 6$ & .817 & -.120 & -.025 & -.208 & -.096 \\
$\times 1$ & .243 & -.228 & -.557 & .494 & -.091 \\
$\times 8$ & .562 & -.489 & -.047 & .347 & -.128 \\
$\times 9$ & -.623 & -.117 & .467 & .332 & -.029 \\
$\times 10$ & .533 & -.261 & .475 & .186 & .093 \\
$\times 11$ & .222 & .809 & -.073 & -.069 & .004 \\
$\times 12$ & .320 & .754 & -.129 & .034 & .048 \\
$\times 13$ & -.173 & .379 & -.240 & .572 & -.274 \\
$\times 14$ & .322 & .352 & .232 & .384 & -.321 \\
& .703 & -.017 & .281 & .274 & .145 \\
\hline
\end{tabular}

a.

Dengan demikian ada 5 faktor yang terbentuk. Factor loadings yaitu besarnya korelasi antara masing-masing atribut dengan Faktor 1, Faktor 2, Faktor 3, Faktor 4, dan Faktor 5. Penentuan atribut yang masuk masing-masing faktor dilakukan dengan memperbandingkan besaran korelasi pada setiap baris. Angka korelasi dibawah 0,5 menunjukkan indikasi korelasi yang lemah sedangkan diatas 0,5 berindikasi kuat korelasinya.

5. Melakukan Rotasi Terhadap Faktor

Setelah menentukan banyak faktor maka langkah selanjutnya yaitu melakukan rotasi terhadap faktor. Pada rotasi faktor ini digunakan untuk memperjelas atribut-atribut mana yang masuk ke dalam tiap-tiap faktor. Banyak sekali faktor loading yang berubah setelah mengalami rotasi menjadi lebih kecil atau lebih besar.

Rotated Component Matriæ

\begin{tabular}{|l|r|r|r|r|r|}
\hline & \multicolumn{7}{|c|}{} & & & \\
\hline & & & & & \\
\hline$\times 1$ & -.045 & .062 & .049 & .132 & .938 \\
$\times 3$ & .694 & .493 & .043 & .212 & -.082 \\
$\times 4$ & -.832 & -.102 & -.053 & .028 & -.003 \\
$\times 5$ & .119 & .665 & .409 & -.320 & .056 \\
$\times 6$ & .723 & .443 & .023 & -.001 & -.126 \\
$\times 1$ & .233 & .015 & -.120 & .751 & .202 \\
$\times 8$ & .328 & .517 & -.348 & .446 & -.017 \\
$\times 9$ & -.817 & .025 & -.229 & -.050 & -.093 \\
$\times 10$ & .100 & .762 & -.165 & -.058 & -.013 \\
$\times 11$ & .127 & -.025 & .832 & -.070 & -.006 \\
$\times 12$ & .179 & .054 & .805 & .038 & .076 \\
$\times 13$ & -.326 & -.123 & .390 & .597 & -.059 \\
$\times 14$ & -.094 & .425 & .423 & .282 & -.289 \\
& .239 & .761 & .119 & .088 & .109 \\
\hline
\end{tabular}

Extraction Method: Principal Component Analysis.

a.

Pada rotated matrics factor atribut-atribut yang masuk pada tiap-tiap faktor sebagai berikut: Faktor 1 terdiri dari atribut-atribut 2, 3, 5 dan 8. Faktor 2 terdiri dari atribut-atribut 4, 7, 9,
13 dan 14. Faktor 3 terdiri dari atribut 10 dan atribut 11. Faktor 4 terdiri dari atribut 6 dan atribut 12. Faktor 5 terdiri dari atribut 1. 
6. Menginterpretasikan Faktor

Setelah didapatkan hasil rotasi maka langkah selanjutnya yaitu mengimplementasikan faktor yang hasilnya sebagai berikut.

Component Transformation Matrix

\begin{tabular}{|r|r|r|r|r|r|}
\hline & & & & & \\
\hline 1 & .723 & .654 & .187 & .117 & -.001 \\
2 & -.126 & -.122 & .979 & -.101 & -.020 \\
3 & -.473 & .630 & -.043 & -.532 & -.307 \\
4 & -.485 & .383 & .067 & .750 & .224 \\
5 & -.042 & .114 & -.010 & -.360 & .925 \\
\hline
\end{tabular}

Extraction Method: Principal Component Analysis.

Component transformation matrix dapat dijelaskan bahwa pada diagonal faktor (component) 1, 4 dan 5 jatuh diatas angka 0,5 $(0,723,0,750$ dan 0,925$)$, membuktikan bahwa ketiga faktor (component) yang terbentuk sudah tepat karena mempunyai korelasi yang tinggi. Diagonal component 2 dan 3 menunjukkan angka dibawah 0,5 yang menunjukkan terdapat component lain pada masing-masing faktor yang mempunyai korelasi cukup tinggi. Pada Faktor (component) 2, diagonalnya menunjukkan angka- 0,122. Component 2 pada faktor-faktor 1, 3, 4 dan 5 menunjukkan angka lebih besar. Demikian pula pada faktor (component) 3, dengan angka menunjukkan - 0,04. Dari analisa tersebut diatas, maka terbentuknya Faktor 1, Faktor 4 dan Faktor 5 sudah tepat karena mempunyai korelasi yang tinggi. Faktor 2 dan Faktor 3 mempunyai korelasi yang rendah sehingga masih ada korelasi dengan fakor yang lain. Dengan demikian, antara Faktor 2 dan 3 cenderung terjadi interkorelasi.

\section{Analisis Dan Interpretasi Data}

Pada pengolahan data dengan analisis faktor terdapat 14 atribut yang telah diteliti. Dari 14 atribut ersebut diatas kemudian diolah dengan analisis faktor dengan menggunkan metode PCA (Principal Component Analysis). Tujuan dari analis faktor disini adalah untuk mereduksi dari 14 atribut yang telah diketahui. Dari hasil pengolahan data dengan menggunakan analisis faktor diperoleh hasil 5 faktor.

Tabel 1 : Hasil Analisis Faktor Dari 14 atribut

\begin{tabular}{|l|l|}
\hline Faktor & atribut yang mewakili \\
\hline Faktor 1 & atribut $2:$ Warna \\
& atribut $3:$ Kerapian \\
& atribut $5:$ Bahan \\
& atribut $8:$ Merek \\
\hline
\end{tabular}

\begin{tabular}{|l|l|}
\hline Faktor 2 & $\begin{array}{l}\text { atribut 4: Hasil Tenunan } \\
\text { atribut 7 : Tulisan Pada Kemasan } \\
\text { atribut } 9: \text { Harga kompetitif } \\
\text { atribut 13: Lokosi Penjualan } \\
\text { atribut 14: Persediaan Barang }\end{array}$ \\
\hline Faktor 3 & $\begin{array}{l}\text { atribut 10: Pemberian Diskon } \\
\text { atribut 11: Harga Sesuai Kualitas }\end{array}$ \\
\hline Faktor 4 & $\begin{array}{l}\text { atribut } 6: \text { Kemasan } \\
\text { atribut 12: Promosi }\end{array}$ \\
\hline Faktor 5 & atribut 1: Jenis \\
\hline
\end{tabular}

1. Faktor 1 diberi label kualitas dan merek (jumlah kumulatif sebesar $28.6 \%$ ) yang mewakili

- Atribut 2 yaitu warna dengan loding sebesar 0.694.

- Pada atribut warna ini menunjukkan bahwa pada sarung tenun ikat memiliki ciri bahwa kombinasi warnanya beragam, sesuai dengan selera konsumen.

- Atribut 3 yaitu kerapian dengan loding sebesar 0.832 .

- Atribut kerapian memberikan dampak terhadap hasil sarung tenun ikat yang dihasilkan. Apabila Lamongan bisa memproduksi sarung tenun ikat dengan memperhatikan hasil tenunan sesuai dengan konsumen maka akan meningkatkan kapasitas produksi.

- Atribut 5 yaitu jenis bahan dengan loding sebesar 0.723 .

- Atribut jenis bahan yang digunakan ini memberikan dampak terhadap keawetan sarung tenun ikat.

- Atribut 8 yaitu merek dengan loding 0.817 .

- Pada atribut merek ini dibuat dengan sederhana oleh perusahaan agar para konsumen mudah mengingat mereknya.

2. Faktor 2 diberi label ketersediaan dipasar (jumlah kumulatif sebesar $14.4 \%$ ) yang mewakili yaitu:

- Atribut 4 yaitu hasil tenunan dengan loding 
sebesar 0.665 .

Sarung tenun ikat yang diproduksi di Lamongan menghasilkan tenunan yang halus. Sehingga memberikan kenyamanan kepada pemakainya dan tidak mengalami gangguan pada saat memakai yang dikarenakan karena hasil tenunan yang kasar.

- Atribut 7 yaitu tulisan pada kemasan dengan loding sebesar 0.517 .

Atribut tulisan pada kemasan dibuat oleah perusahaan semenarik mungkin sehingga membuat konsumen tertarik terhadap tulisan yang ada pada kemasan sarung tenun ikat.

- Atribut 9 yaitu harga kompetitif dengan loding sebesar 0.762 .

Yang dimaksud dengan atribut harga kompetitif disini yaitu harga yang ditawarkan sesuai dengan mekanisme pasar.

- Atribut 13 yaitu lokasi penjualan dengan loding sebesar 0.425 .

Atribut lokasi penjualan yang dimaksudkan adalah lokasi yang strategis bisa dijangkau oleh para konsumennya. Karena produk ini tidak dijual pada satu tempat saja.

- Atribut 14 yaitu persedian barang dengan loding sebesar 0.761 .

Atribut persedian produk disini yaitu bahwa perusahaan menyediakan stok produk yaitu sarung tenun ikat sehingga konsumen tidak perlu memesan terlebih dahulu.

3. Faktor 3 diberi label harga dan diskon (jumlah kumulatif sebesar $10.1 \%$ ) yang mewakili yaitu:

- Atribut 10 yaitu pemberian diskon dengan loding sebesar 0.832 .

Sarung tenun ikat memberikan diskon pada beberapa produknya dalam jumlah pembelian partai besar.

- Atribut 11 yaitu harga dengan loding sebesar 0.805 .

Atribut harga disini adalah menawarkan sarung tenun ikat sesuai dengan kualitasnya. Maka semakin kualitasnya bagus maka harga semakin mahal.

4. Faktor 4 diberi label kemasan dan promosi (jumlah kumulatif sebesar 9.9\%) yang mewakili yaitu :

- Atribut 6 yaitu kemasan dengan loding sebesar 0.751 .

Kemasan yang dibuat sangat menarik yaitu dari segi warna atau dari bahan yang digunakan untuk kemasan.
- Atribut 12 yaitu promosi dengan loding sebesar 0.597 .

Promosi yang dilakukan oleh sarung tenun ikat ini dibuat dengan menarik yaitu dari segi brosur, pameran, pamflet atau yang lainnya.

5. Faktor 5 Diberi label jenis (jumlah kumulatif sebesar $7.2 \%$ ) yang mewakili yaitu :

- Atribut 1 yaitu jenis dengan loding sebesar 0.938 .

Jenis sarung tenun ikat yang ditawarkan bermacam - macam seperti tenun botolan, tenun tempel botolan, tenun sutra, tenun timbul dan tenun songket. Sehingga konsumen dapat memilih sesuai dengan keinginannya.

Jumlah kumulatif dari kelima faktor diatas kurang dari $100 \%$, hal ini disebabkan karena masih ada factor-faktor lain yang mungkin belum terungkap yang mempengaruhi pembeli sarung tenun ikat. Dari kelima faktor diatas bisa diketahui bahwa faktor yang paling dominan yang mempengaruri kecenderungan minat beli konsumen dalam memilih sarung tenun ikat adalah faktor kualitas dan merek. Yang termasuk dalam faktor 1 adalah atribut 2 (warna), atribut 3 (kerapian), atribut 5 (bahan) dan atribut 8 (merek). Hal ini disebabkan karena kualitas merupakan faktor yang terdapat dalam sebuah produk yang menyebabkan produk tersebut bernilai. Sedangkan faktor merek merupakan nama, istilah, istilah, tanda, dan simbol yang dimaksudkan untuk mengidentifikasi suatu produk. Sehingga merek dapat mempengaruhi kecenderungan minat beli konsumen terhadap sarung tenun ikat.

\section{KESIMPULAN}

Berdasarkan pembahasan dan analisis penelitian yang telah diuraikan sebelumnya maka dapat diambil kesimpulan yang berkaitan dengan hasil penelitian ini diantaranya adalah sebagai berikut :

1. Dari hasil pengolahan data 100 responden yang diteliti didapatkan bahwa identifikasi atribut kualitas terhadap sarung tenun ikat adalah jenis sarung tenun ikat beragam, warna sarung tenun ikat, kerapian tenunan sarung tenun ikat, hasil tenunan sarung tenun ikat, bahan tidak mudah koyak, kualitas sesuai dengan harga.

2. Dari hasil analisis analisis faktor yang dilakukan untuk 100 responden yang diteliti, terdapat 5 faktor dari 14 atribut yang telah 
diteliti dalam memilih sarung tenun ikat adalah kualitas dan merek, ketersediaan dipasar, harga dan diskon, kemasan dan promosi serta jenis. Dari kelima faktor tersebut bisa diketahui bahwa faktor yang paling dominan yang mempengaruri kecenderungan minat beli konsumen dalam memilih sarung tenun ikat adalah faktor kualitas dan merek. Yang termasuk dalam faktor 1 adalah atribut 2 (warna), atribut 3 (kerapian), atribut 5 (bahan) dan atribut 8 (merek).

\section{DAFTAR PUSTAKA}

Abdurachman, Ujianto, "Analisis Faktor-Faktor yang Menimbulkan Kecenderungan Minat Beli Konsumen Sarung (Studi Perilaku Konsumen Sarung di Jawa Timur)”. Jurnal Ekonomi Universitas 17 Agustus. www.google. com, Diakses 20 Maret 2008.

Agung, Bhuono Nugroho SE, M.Si., Akt., 2005, "Strategi Jitu Memilih Metode Statistik Penelitian dengan SPSS", Andi, Yogyakarta.

Almah, Buchori Prof. DR. 2005, "Manajemen Pemasaran dan Pemasaran Jasa", Alfabeta, Bandung.

Kotler, Philip, 2005, "Manajemen Pemasaran", PT INDEKS kelompok Gramedia, Jakarta.

Alison, Morrison and John Breen. 2003. Small Business Growth Intention, Ability and Opportunity. Journal of Small Business Management. Vol. 41 No. 4. October pp. 417425.

Arikunto, Suharsimi. 1996. Prosedur Penelitian Suatu Pendekatan Praktek. Cetakan 8. Yogyakarta: Rineka Cipta.

Chrisman, J.J and W. E. Mullan. 2002. Some Addetional Comments on The Sources and Measurement of The Benefit of Small Business Assistance Program. Journal of Business. 40(1), pp. 43-50.

Data Base Industri dan Perdagangan Kabupaten Lamongan Tahun 2004, Diterbitkan oleh Dinas Perindustrian, Perdagangan dan Koperasi Kabupaten Lamongan.

Depperindag. 2002. Rencana Induk Pengembangan Industri Kecil Menengah 2002-2004. Buku 1 Kebijakan dan Strategi Umum Pengembangan Industri Kecil Menengah. Hal. 45.

Ferrinadewi, Erna \& Didit Darmawan, 2004,
"Perilaku Konsumen : Analisis Model Keputusan”, Universitas Atma Jaya, Yogyakarta.

Ferdinant, Augusty. 2000. Struktural Equation Modeling (SEM) Dalam Penelitian Manajemen. Semarang: Universitas Diponegoro.

Gunawan, Hery. 2002. Problematik Pengembangan Industri Kecil dan Jalan Keluarnya. Masukan bagi UU No. 9 Tahun 1995 tentang Usaha Kecil. Usahawan. No. 12 Tahun XXXI desember, hal 54.

Hafsah, Moh Jafar. 2000. Kemitraan Usaha. Konsepsi dan Strategi. Cetakan Kedua. Jakarta: Pustaka Sinar Harapan.

Hakim, Abdul. 2002. Ekonomi Pembangunan. Yogyakarta: Ekonosia.

Harimurti, Subanar. 1998. Manajemen Usaha Kecil. Edisi Pertama, Cetakan Ketiga. Yogyakarta: BPFE.

Hindle, Kewin and Cutting Neil. 2002. Can Aplied Entrepreneurship Education Enhance job Satisfaction and Financial Performance. An Empirical Investigation in The Australian Pharmacy Proffession. Journal of Small Business Management. Milwauke: Vol. 40 No. 2. pp. 162-168.

Ismail, Rizal. 2002. Terobosan Pemulihan Ekonomi Indonesia, Upaya Strategis Pemulihan Ekonomi dan Mengatasi Kemiskinan Melalui Pengembangan Usaha Kecil Menengah. Jakrta: Penerbit Forum Kampus Kuning. Hal 50-60.

Komite Penanggulangan Kemiskinan. 2004. Pedoman Umum dan Petunjuk Tejnis. Program Kredit Uasaha Mikro Layak Tanpa Agunan (KUM-LTA). Jakarta Pusat 10110.

Mahon, Richard G.P. 2001. Business Growth and Performance and The Financial Reporting Practices of Australian Manufacturing SMES. Journal of Business Management. Vol. 39 No. 2. pp. 152.

Mubyarto. 2001. Pemberdayaan Ekonomi Rakyat dan Peranan Ilmu-ilmu Sosial. Yogyakarta: Yayasan Agro-Ekonomika.

Mubyarto. 2000. Membangun Sistem Ekonomi. BPFE Yogyakarta: BPFE.

Prawirokusumo, Soeharto. 2001. Ekonomi Rakat (Konsep, Kebijakan dan Strategi). Yogyakarta: BPFE.

Riduwan. 2004. Metode dan Teknik Penyusunan 
Tesis. Cetakan 2. Bandung: Alfabeta.

Solimun. 2003. Structural Equation Modeling LISREL dan AMOS. Fakultas MIPAUniversitas Brawijaya.

Tambunan. T. 2002. Usaha kecil dan Menengah di Indonesia. Beberapa Isu Penting. Edisi Pertama. Jakarta: Salemba Empat.

Wibowo, Murdina F. 2002. Pedoman Mengelola Perusahaan Kecil. Jakarta: Penerbit PT Penebar Swadaya.

Widodo, Sri. 2003. Peran Agribisnis Usaha Kecil Menengah untuk Memperkokoh Ekonomi Nasional. Edisi Pertama, Cetakan Pertama. Yogyakarta: Liberty.

Vasant, Desai. 2003. Management of A SmallScale Industry. Tenth Edition. Mumbay, India: Himalaya Publishin House. 